\title{
\begin{tabular}{lllllllllllllllll}
$\mathbf{A}$ & $\mathbf{R}$ & $\mathbf{T}$ & $\mathbf{Y}$ & $\mathbf{K}$ & $\mathbf{U}$ & $\mathbf{L}$ & $\mathbf{Y}$ & $/$ & $\mathbf{A}$ & $\mathbf{R}$ & $\mathbf{T}$ & $\mathbf{I}$ & $\mathbf{C}$ & $\mathbf{L}$ & $\mathbf{E}$ & $\mathbf{S}$ \\
\hline
\end{tabular} \\ ROCZNIKI KULTUROZNAWCZE \\ Tom/Vol. XI, numer/number $4 \quad-\quad 2020$ \\ DOI: http://doi.org/10.18290/rkult20114-1
}

DOMINIQUE POIREL

\section{WHAT DOES THE MIDDLE AGES TEACH US FOR TODAY?}

\section{INTRODUCTION}

What can we learn from the Middle Ages? How does our knowledge of the millennium from around 500 to 1500 A.D. help us to understand the times in which we live? Asking this question requires the resolution of several others. First, what are the Middle Ages? Did one Middle Ages really exist as a collection of centuries with a real unity, or was there really only a succession of eras as different from each other as each is from ours? Secondly, can history help us for the present, when its aim seems rather to be to make us know and understand, not without difficulties, not without uncertainties, a past that slips away as we move away from it? Is it not, conversely, our commitment to the present that helps us to question the past in an ever-renewed way, in order to discover, generation after generation, complementary aspects that had escaped our predecessors? Assuming, moreover, that there is one Middle Ages and that we can learn from it about what we are experiencing, how will we use these lessons? As a reminder of ancient disasters that we should avoid today? Or as a model of ancient successes that we should imitate? Or as a warning that the course of events obeys subterranean causes that are all the more inevitable, and that it is therefore not in our power to change? Or finally, as the spectacle of events that are always complex and confusing, which man can hardly explain after

Prof. Dominique Poirel - Institut de Recherche et d'Histoire des Textes \& Centre National de Recherche Scientifique, France; John Paul II Catholic University of Lublin, Faculty of Philosophy, Institute of Philosophy, Department of the History of Ancient and Medieval Philosophy; e-mail: dominique.m.c.poirel@ gmail.com; ORCID: https://orcid.org/0000-0001-7383-1110. 
the fact, once they have taken place, let alone anticipate and foresee them before they happen? In spite of all these objections and all the other similar ones that could be formulated, I will nevertheless try to answer the question: "What does the Middle Ages teach us for today?" as a medievalist interested in the history of texts and ideas. Why is this so? Because it is impossible for the historian engaged in his time not to confront the period he is studying with the one in which he lives, in order to try to understand one by the other. Who knows, moreover, if the survey will not give us unexpected avenues for reflection?

Assuming, then, that there is one Middle Ages, what is its unity? We will propose this assessment: The Middle Ages is that long period in which a common European civilisation was shaped by the integration of the most diverse peoples and legacies, like the childhood of our Western modernity. This integration was made possible by two main features: from the end of the Roman Empire to the great discoveries, medieval times had a common admiration, one could almost say an inferiority complex, before the ancient times that preceded them: Athens, Rome and Jerusalem. This veneration of the Ancients, of the Fathers, was not, however, sterilizing; on the contrary, it provided ideal models, towards which medieval times never ceased to rise, without ever reaching them, but paradoxically creating something new: nothing was more innovative than the impossible desire to return to the origins.

\section{THE SYNTHESIS OF LEGACIES}

For a long time, the Middle Ages was supposed to begin with the "barbarian invasions". From the $4^{\text {th }}$ to the $6^{\text {th }}$ century, the blows of peoples coming from the East (Germans, Huns, Alans, Avars), would have led in the West to the fall of the Roman Empire and the collapse of the ancient civilization. Today, historians are more attentive to continuities. Rather than violent "invasions," it was more often a question of "migrations," often peaceful, or even the enlistment of barbarians in the service of the Empire. Although the last emperor, Romulus Augustulus, whose name is so ironically eloquent, was well deposed in $476,{ }^{1}$ not only did the empire remain in the East until $1453,{ }^{2}$ but the Germanic kingdoms that shared the West retained as best they could

\footnotetext{
${ }^{1}$ See Geoffrey Nathan, “The Last Emperor: The Fate of Romulus Augustulus", Classica et Mediaevalia, no. 43 (1992): 261-271.

${ }^{2}$ See Jonathan Harris, The End of Byzantium (Yale: Yale University Press, 2010).
} 
the earlier administrative and cultural frameworks. ${ }^{3}$ In this way, they became the successors of the Empire, rather than its destroyers. This is why historians readily refer to the period between the $3^{\text {rd }}$ and $8^{\text {th }}$ centuries as "Late Antiquity": just before Charlemagne, supported by the Pope, restored the Roman Empire to the West in the year 800, proving by this very renewal that what he was restoring had previously ceased to exist.

Whatever these population displacements and political changes, one only has to compare the maps of geography over a millennium to realise a feature that confirms the existence of a Middle Ages. While in ancient times the Mediterranean Sea was the natural space for circulation between the dominant civilisations, in the Middle Ages four new developments changed this situation: 1) the Limes, the fortified border that separated the Roman Empire from the outside world, disappeared; 2) little by little, the Latin West diverges politically, economically, culturally and religiously from the Greek East; 3) suddenly, Islam spreads to the Levant, Africa and Spain; 4) as a result, trade moves from the sea to the continent and gradually integrates hitherto marginal regions to the north and east. In this sense, the Middle Ages were the true birth of Europe. In addition to the populations already present in the Roman Empire, from England to the Causasus, not forgetting the Jewish diaspora, others were added over the centuries: mainly Germanic, Celtic, Scandinavian, Magyar, Slavic, Baltic and even Turkish-speaking, to which was added the reconquest of territories that had been separated by invasion, such as Spain. As a result, a major challenge in the Middle Ages was the fusion of all these heritages, linguistic, cultural and religious, to shape a common civilisation from diverse populations.

The new peoples joined their predecessors following processes that were sometimes peaceful and sometimes bellicose, but always the diplomatic or military attachment was finally validated by religious conversion, free as in Ireland and Scotland in the $5^{\text {th }}$ century, or forced as in Saxony under Charlemagne (d. 814). Thus the Slavic countries in the $9^{\text {th }}-11^{\text {th }}$ centuries, Scandinavia in the $10^{\text {th }}-11^{\text {th }}$ centuries, Hungary in the year 1000 , the Cumans in the $11^{\text {th }}$ century, and the Baltic countries in the $13^{\text {th }}-14^{\text {th }}$ centuries joined Latin or Greek Christianity one after the other and became part of the concert of European peoples.

\footnotetext{
${ }^{3}$ Walter A. Goffart, Barbarians and Romans AD 418-584. The Techniques of Accommodation (Princeton: Princeton University Press, 1980); Peter J. Heather, The Fall of the Roman Empire. A New History (London: Macmillan, 2005).
} 
From the $14^{\text {th }}$ century onwards, a succession of crises seemed to halt the process: while famines and plagues reduced the European population by about a third and the Muslim enemy increased its pressure, first on the Levant, soon on the eastern part of Europe, the Western European states clashed in interminable wars, such as the Hundred Years' War between England and France, and were affected by an epidemic of civil wars: Jacques van Artevelde's uprising in Flanders (1337-1345), War of Succession in Castile (1351-1369), Etienne Marcel's uprising in France (1357-1358), War of the Armagnacs and Burgundians in France (1407-1435), War of the Roses in England (1455-1485). The Church itself, although preaching peace between Christian nations, was cruelly torn apart by the Great Schism of the West (1378-1417), the harbinger of future schisms such as the Hussite Revolution in 1419 and the Protestant Reformation in $1517 .{ }^{4}$

These successive convulsions, which heralded the end of a certain Middle Ages, should not make us forget, however, that for a millennium, from the $5^{\text {th }}$ to the $15^{\text {th }}$ century, a long movement of exchange and assimilation was at work over a vast European area, and even that this movement, far from receding, never stopped progressing despite the crises. For example, this is illustrated by the accelerated multiplication of new universities at the end of the Middle Ages, particularly in kingdoms on the periphery of Latin Christendom: Prague in Bohemia (1347), Krakow in Poland (1364), Pécs in Hungary (1367), Erfurt in Thuringia (1389), St. Andrew's in Scotland (1410), Lund (1425) and Uppsala in Sweden (1477), Copenhagen in Denmark (1479) and many others. ${ }^{5}$ Perhaps the political and religious quarrels were so violent because they were not between strangers, but between brothers who were enemies. Therefore, they should not hide the fact that throughout the Middle Ages a slow but irresistible process brought together people who, a few centuries earlier, did not know each other and enabled them to found together a vast, bubbling but common cultural community, so that what was happening at one end of Europe soon affected all the other parts of the continent. How can this be explained?

\footnotetext{
${ }^{4}$ On this crisis of the late Middle Ages, see Johan Huyzinga, Herfsttij der Middeleeuwen (Leiden: Leiden University Press, 2018; $1^{\text {st }}$ ed. 1919), translated as The Waning of the Middle Ages (London: Penguin Books, 1924). And, more recently, Joël Blanchard, La fin du Moyen Âge (Paris: Perrin, 2020).

${ }^{5}$ Hastings Rashdall, Frederick Maurice Powicke, and Alfred Brotherstan Emden, The Universities of Europe in the Middle Ages, 3 vol. (Oxford: Clarendon Press, 1987).
} 


\section{AN INFERIORITY COMPLEX}

Perhaps because of what could be called a kind of inferiority complex of medieval men in relation to distant and prestigious Ancients. Whether biblical, classical or patristic authors, these Fathers aroused such great and general admiration that no one considered it possible to equal them. Such admiration might seem sterilizing; but quite the opposite happened. From the $12^{\text {th }}$ century in particular, this awareness of the superiority of the ancient forefathers was accompanied by the feeling that progress was no less possible. This is expressed in the well-known comparison by Bernard de Chartres:

We are dwarves perched on the shoulders of giants, so that we can see more things and further than they do; not because our sight is more piercing or our height is greater, but because we are elevated and carried high by their great stature as giants.

This sentence can be read in the Metalogicon of John of Salisbury. ${ }^{6}$ It is remarkable that it is not only placed in the mouth of one of his revered masters, Bernard de Chartres, but also taken up after them by other more recent authors such as Pierre de Blois and Alexandre Nequam. ${ }^{7}$ The meaning of the logion they bring back is thus confirmed by the very mode of its transmission. This meaning is of a fertile ambivalence: our elders are taller than we are; but however small we are, since we come after them, their size increased by ours allows us to surpass them. The new times are either declining or progressing in comparison to the old times, depending on the attitude we adopt towards this: ignorance or assimilation.

\footnotetext{
${ }^{6}$ John of SAlisbury, Metalogicon, III, 4: "Dicebat Bernardus Carnotensis nos esse quasi nanos gigantum umeris insidentes, ut possimus plura eis et remotiora uidere, non utique proprii uisus acumine, aut eminentia corporis, sed quia in altum subuehimur et extollimur magnitudine gigantea." Edition: Iohannis Saresberiensis Metalogicon, ed. John Barnie Hall, auxiliante K. S.B. Keats-Rohan, CCCM 98 (Turnhout: Brepols, 1991), 116, lines 47-50 = PL 209, 900C.

${ }^{7}$ Cf. Alexander Nequam, De naturis rerum, I, 78: "Et ut ait philosophus: nos sumus quasi nani stantes super humeros gigantum. Praedecessoribus itaque nostris ascribere tenemur ea quae in gloriam laudis nostrae non nunquam transferre audemus, similes parrae quae levi labore, immo nullo, aquilam vicisse protestata est." Edition: Alexandri Neckham De naturis rerum libri duo, ed. Thomas Wright, Rolls Series, 34 (London: Longman and Green, 1863), 123; PIERrE De Blois, Epistula 92: "Nos, quasi nani super gigantum humeros sumus, quorum beneficio longius, quam ipsi, speculamur, dum antiquorum tractatibus inhaerentes elegantiores eorum sententias, quas vetustas aboleverat, hominumve neglectus, quasi iam mortuas in quamdam novitatem essentiae suscitamus." Edition: PL 207, 290AB. See J. de GHELlinck, "Nani et gigantes,"Archivum Latinitatis Medii Aevi, t. 18 (1943-1944): 25-29; Édouard JEAUNEAU, "Nani gigantum humeris insidentes. Essai d'interprétation de Bernard de Chartres," Vivarium, t. 5, 1967: 79-99, repr. in ID. "Lectio philosophorum". Recherches sur l'École de Chartres (Amsterdam: Adolf M. Hakkert, 1973), 51-74.
} 
The meaning of these words of Bernard of Chartres can be enlightened by another, which Jean de Salisbury quotes again in the Metalogicon and which Hugh of Saint-Victor comments at length in the Didascalicon. Among the circumstances favourable to the study, the first place goes to the virtue of humility:

As a wise man was asked about the method and the model for learning, he said: 'A humble spirit, the ardour to seek, a quiet life, analysis in silence, poverty, a foreign land: this often opens up to many what is read in the dark. ${ }^{8}$

It would be wrong to be too quick to attribute this requirement of humility solely to moral virtues: it is here, above all, an intellectual virtue. This is what Hugh meant when he described it in detail in three points: 1) not to disdain any science or text; 2) not to blush at learning from anyone; 3) not to despise others once educated in science. Even before "ardour to seek," humility is described as the most necessary condition, the most powerful motor for progress in knowledge. Those who boast of their instruction or their masters, no longer have the taste for learning in them, they are too soon satisfied. "This is enough for you: you have drunk from the very source of philosophy; but may you still be thirsty!" In the end, this humility is in principle the awareness of a lack and consequently the desire to progress, to continue to learn indefinitely. This methodical humility is basically an indefinite receptivity to all knowledge:

Therefore the wise reader listens to everyone willingly, he reads everything, he does not disdain any text, any person, any teaching. He seeks from everyone indifferently what he sees himself lacking, and does not consider the extent of his knowledge, but that of his ignorance. ${ }^{9}$

Of course, this humility was not equal between all eras nor between all the masters of the Middle Ages. Nevertheless, it remains the backdrop of this millennium that we call medieval, especially in its Latin and Western versions. Medieval humility towards the Ancients was the result of the painful awareness of a distance from them, and at the same time of a persistent effort to overcome it. This makes a difference both with Antiquity itself, where this distance did not yet exist or was much less, and with Modernity,

\footnotetext{
${ }^{8}$ Didascalicon, III, 12: "Sapiens quidam cum de modo et forma discendi interrogaretur: 'Mens, inquit, humilis, studium quaerendi, vita quieta, / Scrutinium tacitum, paupertas, terra aliena, / Haec reserare solent multis obscura legendi'.” Ed. C. Buttimer, p. 61, lines 11-14.

${ }^{9}$ Didascalicon, III, 13: "Prudens igitur lector omnes libenter audit, omnia legit, non scripturam, non personam, non doctrinam spernit. Indifferenter ab omnibus quod sibi deesse videt quaerit, nec quantum sciat, sed quantum ignoret, considerat.” Ed. C. Buttimer, p. 62, lines 20-23.
} 
which not only does not suffer from this distance, but approves of it and builds on it, even seeking to accelerate it. It also makes a difference with the Renaissance, since this period, at the crossroads between the Middle Ages and modern times, depreciates the near past in contrast to the distant past and takes pride in rediscovering Antiquity, which it admires, beyond the intermediate and dark ages, which it disdains.

This medieval relationship to the past is expressed in many ways. In terms of the way of writing, it explains the important place occupied in the scholarly literature of the Middle Ages by literary forms such as commentary, gloss, sermon, centon, florilegia, compilation, continuation, interpolation, translation and imitation of all kinds. ${ }^{10}$ If "to write is always to rewrite", ${ }^{11}$ never has this general statement been so true as in medieval times, when one distinguishes, on the one hand, the "authorities", i.e. those works, often ancient, which are authoritative in a discipline and which it is important to transmit and know to the letter: Euclid in geometry, Aristotle in logic, Justinian in law, the Bible and the Fathers in theology, etc. ${ }^{12}$ On the other hand, there is a whole literature derived from these "authorities," which consists of quoting, glossing, teaching, exposing, assimilating and adapting them to everchanging audiences.

The importance of the commentary is the transposition into writing of Bernard de Chartres's sentence: "we are dwarves perched on the shoulders of a giant". ${ }^{13}$ Contrary to what one might think, it does not lead to an intellectual attitude of passivity; but the confrontation with texts and thoughts that are distant in time, sometimes also in space, language and culture, was on the contrary a powerful intellectual stimulation to forge concepts, invent conciliations, imagine new answers to questions of yesteryear. To comment is therefore not to repeat, but to update. In reality, we observe this paradox in the Middle Ages: the more one try to remain faithful to the past, the more one actually innovates. This is why the exercise of commentary often gave rise to the most original and personal doctrines: thus from Gilbert de la Por-

\footnotetext{
${ }^{10}$ On literary genres in the Middle Ages, see the collection Typologie des sources du Moyen Âge Occidental, founded in 1972 by Léopold Génicot.

${ }^{11}$ About writing and rewriting in Middle Ages, see Écriture et réécriture des textes philosophiques médiévaux. Volume d'hommage offert à Colette Sirat, Textes et études du Moyen Age (Turnhout: Brepols, 2006).

${ }^{12}$ See Auctor et auctoritas. Invention et conformisme dans l'écriture médiévale. Actes du colloque tenu à l'Université deVersailles - Saint-Quentin-en-Yvelines (14-16 juin 1999), Mémoires et documents de l'École des chartes, 59 (Paris: École nationale des chartes, 2001).

${ }^{13}$ See Commenter au Moyen Âge, ed. Pascale Bermond et Isabelle Moulin (Paris: Vrin, 2020).
} 
rée in the $12^{\text {th }}$ century, whose entire work is only exegetical. The word renovatio, which oscillates between refurbishment and renewal, the return to the identical and the replacement by another, expresses well this medieval dialectic of nostalgia and progress, where the effort to return to ancient times is the most powerful engine of change and rejuvenation.

This is why the Middle Ages is a succession of renaissances: "The Ostrogothic Renaissance of the $6^{\text {th }}$ century at the time of Boethius and Cassiodorus; the Visigothic Renaissance of the $7^{\text {th }}$ century at the time of Isidore of Seville; the Northumbrian Renaissance of the $8^{\text {th }}$ century at the time of Bede the Venerable; the Carolingian Renaissance of the $9^{\text {th }}$ century at the time of Alcuin; the Ottonian Renaissance around the year 1000, at the time of Abbo of Fleury and Gerbert of Aurillac; the Renaissance of the $12^{\text {th }}$ century at the time of Bernard of Chartres and many others; the renaissance of peripateticism at the time of the universities $\left(13^{\text {th }}-14^{\text {th }}\right.$ centuries $)$; Italian Renaissance or pre-Renaissance at the time of Dante, Petrarch and Boccaccio $\left(14^{\text {th }}\right.$ centuries), and one arrives imperceptibly at the Renaissance proper throughout Europe. ${ }^{14}$ What is true in the order of Letters, Arts and Thought is also true about religious life: almost every century or so had its attempt to reform the Church, up to the Reformation proper, which separates itself from previous reforms by the fact that it aspires, like the Renaissance, to span the medieval centuries to reach the purity of the origins.

\footnotetext{
${ }^{14}$ See Ema Patzelt who speaks of a 'Carolingian Renaissance' in her book Die Karolingische Renaissance. Beiträge zur Geschichte der Kultur des frühen Mittalters (Wien: Österreichischer Schulbücherverlag, 1924). Three years later Hans Naumann calls the Ottonian times a 'Renaissance,' in his book Karolingische und ottonische Renaissance (Frankfurt am Main: Englert und Schlosse, 1927), and Charles Homer Haskins does the same for the $12^{\text {th }}$ century, in The Renaissance of the Twelfth Century (Cambridge: Cambridge, University Press, 1927), a notion that is now used by most of the historians, see for instance Jacques Verger, La Renaissance du XII ${ }^{e}$ siècle, Initiations au Moyen Âge (Paris: Cerf, 1999). Finally, Pierre Riché admits Ostrogothic, Isidorian and Carolingian Renaissances in Éducation et culture dans l'Occident barbare, VI VIII siècle, Patristica Sorbonensia, 4 (Paris: Seuil, 1962), Carol L. Neuman de Vegvar writes The Northumbrian Renaissance: a study in the transmission of style (Cranbury: Associated University Press, 1987) and Jacques Fontaine devotes a conference to L'Europe héritière de l'Europe wisigothique, ed. Jacques Fontaine and Christine Pellistrandi (Madrid: Casa de Velazquez, 1992). Jean-Jacques Ampère seems the first to use the word of 'Renaissance' for the Middle Ages, for instance in Histoire littéraire de la France avant le XIII ${ }^{e}$ siècle (Paris: Hachette, 1838).
} 


\section{A DEEP PLURALISM}

Another feature that characterises the Middle Ages is partly derived from the above. It is a constant tension between the one and the multiple. On the one hand, there is a strong desire everywhere to find a kind of lost unity; on the other hand, this desire for unity is not simple but plural. In fact, there are several universalist principles, inherited from Antiquity, on which the medieval universe relies to think about its own order: first of all the Christian faith, of course, but also Greek wisdom and Roman law, and these three diverse principles create a tug of war that was very fruitful. The Christian faith is based on the biblical scriptures, Greek wisdom on the books of the philosophers, and Roman law on the corpus of Justinian. The Christian faith teaches that everything comes from God and returns to him, through Christ and in the Church; Greek wisdom explores the foundations of reality and the end of man, in the light of reason; Roman law seeks to regulate relations between men, within the framework of the law. Christ, reason and law are not incompatible, but these three unifying principles, symbolised by Jerusalem, Athens and Rome, variously draw the same medieval universe, giving it three distinct and competing orientations: each has legitimate claims to autonomy and universality.

This polycentrism was not only the cause of a long series of clashes and conflicts between pastors, scholars and princes; since sooner or later antagonistic pressures had to be reconciled, spaces for debate and flexibility opened up, especially in schools and universities, to tune reason and faith, to adjust theory and life in common, to reconcile Church and Empire. As the commentary was the literary form that summed up par excellence the relationship of medieval authors to a past that they revered, transmitted and constantly adapted, so here the quaestio is the literary form that best expresses this slow work of confrontation and gradual adjustment, in an effort to think together about the antagonistic demands. ${ }^{15}$ Ritual dispute in universities is the place where questions de quolibet, "on any subject," are freely posed, debated in a contradictory manner and "determined" by the authority of the teacher; it is up to the latter to resolve them by integrating into a new construction everything that was said to be admissible during the debate. The search for truth thus manifests itself as a progressive and collective construction, alternating controversy, condemnation and conciliation. The intel-

\footnotetext{
${ }^{15}$ On quaestio and disputatio in the Middle Ages, see Olga WeIJERs, In Search of the Truth: A History of Disputation Techniques from Antiquity to Early Modern Times, Studies on the Faculty of Arts, History and Influence, 1 (Turnhout: Brepols, 2013).
} 
lectual fecundity of the Middle Ages stems largely from the fact that none of these three competing principles of unification absorbed the others, but that successive masters constantly strove to reconcile them, not by juxtaposing them eclectically, but by patiently and methodically articulating them with each other, to convert discordances into concordances.

Three themes of the Christian faith may have fostered this tension between a strong aspiration for unity and the maintenance of a de facto pluralism. Firstly, the mystery of the Trinity. To profess that everything was created by a triune God is to teach that plurality, far from being an accident, a decline in relation to primordial unity, can in some way be reconciled with it. ${ }^{16}$ Secondly, the division of the Bible into an Old and a New Testament. The fact that Christians receive as holy books the founding texts of another, earlier and divergent religion requires an original hermeneutic to decipher in the turbulent history of the Hebrew people the prophetic announcements of Christ, his Passion and Resurrection. Whether it was in turn peaceful and violent, courteous and polemical, it does not prevent it: dialogue with those outside is consubstantial with the Christian faith. ${ }^{17}$ Finally, the Augustinian opposition of the two cities. ${ }^{18}$ In contrast to the ancient and modern worlds, the men of the Middle Ages did not so much aspire to stability here on earth as they knew they were travellers, itinerant, always on the road to a heavenly homeland that they would only reach through death. In this sense, the medieval millennium is truly a "middle" age, tensed between a prestigious origin and a glorious end. There is no question of coinciding with oneself, of settling into illusory permanencies, but of reaching out indefinitely towards something else: that heavenly Jerusalem of which all earthly cities, even the best, can only be very imperfect and temporary imitations.

\section{CONCLUSION}

Migration, the relationship to the past and the future, intellectual and religious tensions between various universal principles... in a renewed way, our

${ }^{16}$ On Trinity in the Middle Ages, see for instance The Oxford Handbook of the Trinity, ed. Gilles Emery and Matthew Levering (Oxford: Oxford University Press, 2011).

${ }^{17}$ On these questions, see Gilbert DaHAN, Les intellectuels chrétiens et les juifs au Moyen Âge, Patrimonies, Judaïsme (Paris: Cerf, 1990); IDEM, L'exégèse chrétienne de la Bible en Occident médiéval, XII ${ }^{e}-X I V^{e}$ siècle, Patrimoines, Christianisme (Paris: Cerf, 1999).

${ }^{18}$ Augustine, De Civitate Dei, ed. Bernard Dombart Alphonsus Kalb, Corpus Christianorum, Series Latina, 47-48 (Turnhout: Brepols, 1955). 
time is facing the same challenges as the medieval millennium. Hence our initial question: how can knowledge of this period inspire us today? We will be forgiven, however, for not answering the question: to do so would be beyond our competence as historians. As such, we have endeavoured to describe in broad strokes what the medieval period has to offer in order to feed contemporary reflection. It is then up to each individual to carry out this reflection on his or her own behalf.

\section{BIBLIOGRAPHY}

AMPÈRE, Jean-Jacques. Histoire littéraire de la France avant le XIII ${ }^{e}$ siècle. Paris: Hachette, 1838.

Augustine. De Civitate Dei, edited by Bernard Dombart and Alphonsus Kalb. Corpus Christianorum, Series Latina, 47-48. Turnhout: Brepols, 1955.

Bermond, Pascale, and Isabelle Moulin (eds.). Commenter au Moyen Âge. Paris: Vrin, 2020.

Blanchard, Joël. La fin du Moyen Âge. Paris: Perrin, 2020.

Dahan, Gilbert. Les intellectuels chrétiens et les juifs au Moyen Âge. Patrimonies, judaïsme. Paris: Cerf, 1990.

Dahan, Gilbert. L'exégèse chrétienne de la Bible en Occident médiéval, XII -XIV siècle. Patrimoines, Christianisme. Paris: Cerf, 1999.

Emery, Gilles, and Matthew Levering (eds). The Oxford Handbook of the Trinity. Oxford: Oxford University Press, 2011.

Fontaine, Jacques, and Christine Pellistrandi. L'Europe héritière de l'Europe wisigothique. Madrid: Casa de Velazquez, 1992.

GhellincK, Joseph. "Nani et gigantes.” Archivum Latinitatis Medii Aevi 18 (1943-1944): 25-29.

Goffart, Walter A. Barbarians and Romans AD 418-584. The Techniques of Accommodation, Princeton: Princeton University Press, 1980.

Heather, Peter J. The Fall of the Roman Empire. A New History. London: Macmillan, 2005.

Hamesse, Jacqueline, and Olga WeIJERs. Écriture et réécriture des textes philosophiques médiévaux. Volume d'hommage offert à Colette Sirat. Textes et études du Moyen Age. Turnhout: Brepols, 2006

HARris, Jonathan. The End of Byzantium. Yale: Yale University Press, 2010.

Haskins, Charles Homer. The Renaissance of the Twelfth Century. Cambridge: Cambridge University Press, 1927.

Hugh of Saint-Victor. Didascalicon, edited by Charles Henry Buttimer: Hugonis de Sancto Victore. Didascalicon. De Studio Legendi. Washington: Catholic University Press, 1939; English translation of Jerome Taylor: The Didascalicon of Hugh of St Victor. New York: Columbia University Press, 1961; and the recent translation of Franklin T. Harkins in: Franklin T. HARKINS and Frans VAN LIERE (eds). Interpretation of scripture: theory. A selection of works of Hugh, Andrew, Richard and Godfrey of St Victor, and of Robert of Melun. Turnhout: Brepols, 2012.

Huyzinga, Johan. Herfsttij der Middeleeuwen. Leiden: Leiden University Press, $2018\left(1^{\text {st }}\right.$ ed. 1919). Translated as The Waning of the Middle Ages. London: Penguin Books, 1924. 
JEAUnEau, Éduard de. “Lectio philosophorum”. Recherches sur l'École de Chartres, 51-74. Amsterdam: Adolf M. Hakkert, 1973.

JEAunEau, Éduard de. "Nani gigantum humeris insidentes. Essai d'interprétation de Bernard de Chartres." Vivarium 5 (1967): 79-99. DOI: https://doi.org/10.1163/156853467X00078.

John of SAlisbury. Metalogicon, edidit John Bernie Hall, auxiliante K.S.B. Keats-Rohan: Iohannis Saresberiensis Metalogicon. Corpus Christianorum Continuatio Mediaevalis, 98. Turnhout: Brepols, 1991.

Nathan, Geoffrey. "The Last Emperor: The Fate of Romulus Augustulus." Classica et Mediaevalia 43 (1992): 261-271.

Naumann, Hans. Karolingische und ottonische Renaissance. Frankfurt am Main: Englert und Schlosse, 1927.

Neuman de Vegvar, Carl L. The Northumbrian Renaissance: a study in the transmission of style. Cranbury: Associated University Press, 1987.

Patzelt, Ema. Die Karolingische Renaissance. Beiträge zur Geschichte der Kultur des frühen Mittalters. Wien: Österreichischer Schulbücherverlag, 1924.

Pierre de Blois. Epistula 92. PL 207, 290AB.

Rashdall, Hastings, Frederick Maurice Powicke, and Alfred Brotherstan Emden. The Universities of Europe in the Middle Ages, 3 vol. Oxford: Clarendon Press, 1987.

RIchÉ, Pierre. Éducation et culture dans l'Occident barbare, VI $I^{e}$-VIII siècle. Patristica Sorbonensia, 4. Paris: Seuil, 1962.

Verger, Jacques. La Renaissance du XII siècle. Initiations au Moyen Âge. Paris: Cerf, 1999.

Weijers, Olga. In Search of the Truth: A History of Disputation Techniques from Antiquity to Early Modern Times. Studies on the Faculty of Arts, History and Influence, 1. Turnhout: Brepols, 2013.

Wright, Thomas (ed.). Alexandri Neckham De naturis rerum libri duo. Rolls Series, 34. London: Longman and Green, 1863.

Zimmermann, Michel (ed.), Auctor et auctoritas. Invention et conformisme dans l'écriture médiévale. Actes du colloque tenu à l'Université deVersailles - Saint-Quentin-en-Yvelines (14-16 juin 1999). Mémoires et documents de l’École des chartes, 59. Paris: École nationale des chartes, 2001.

\section{WHAT DOES THE MIDDLE AGES \\ TEACH US FOR TODAY?}

\section{Su m mary}

Insofar as it is possible to use history to understand one's time, three main lessons can be drawn from the study of the Middle Ages. First, repeated confrontation with new populations did not prevent the foundation of a single cultural community. Then, among the causes that allowed this assimilation, there is what could be called an "inferiority complex," which paradoxically pushed the men of the Middle Ages to constantly innovate out of admiration for their prestigious predecessors. Finally, the desire for unity was allied with numerous tensions and a de facto pluralism, since the poles around which to unify were themselves several: philosophical wisdom inherited from Athens, civil law transmitted from Rome, the Christian faith received from Jerusalem.

Key words: Middle Ages; Europe; Christianity; pluralism; medieval universities; medieval renaissances; Bernard of Chartres; John of Salisbury; Hugh of St. Victor; Augustine of Hippo. 


\section{CZEGO UCZY NAS DZISIAJ ŚREDNIOWIECZE?}

Streszczenie

Na tyle, na ile można posłużyć się historią do zrozumienia swojego czasu, z badań nad średniowieczem można wyciągnąć trzy główne wnioski. Po pierwsze, powtarzająca się konfrontacja z nowymi ludami nie przeszkodziła w powstaniu jednej wspólnoty kulturowej. Po drugie, wśród przyczyn, które pozwoliły na tę asymilację, jest coś, co można by nazwać „kompleksem niższości”, który paradoksalnie popychał ludzi średniowiecza do ciągłego wprowadzania innowacji z podziwu dla swoich prestiżowych poprzedników. Wreszcie pragnieniu jedności towarzyszyły liczne napięcia i faktyczny pluralizm, ponieważ jednoczących biegunów było kilka: filozoficzna mądrość odziedziczona z Aten, prawo cywilne przekazane z Rzymu, wiara chrześcijańska otrzymana z Jerozolimy.

Przetożyt Stanistaw Sarek

Słowa kluczowe: średniowiecze; Europa; chrześcijaństwo; pluralizm; średniowieczne uniwersytety; średniowieczne renesansy; Bernard z Chartres; Jan z Salisbury; Hugon ze Św. Wiktora; Augustyn z Hippony. 